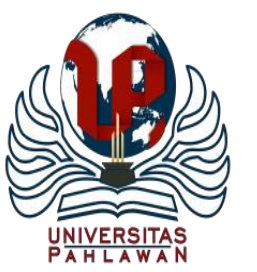

Jurnal Basicedu Volume 4 Nomor 4 Tahun 2020 Halm. 794 - 800

JURNAL BASICEDU

Research \& Learning in Elementary Education

https://jbasic.org/index.php/basicedu/index

\title{
Penggunaan Model Kooperatif Teams Game Turnament Untuk Meningkatkan Keterampilan Sosial Anak Pada Pembelajaran IPS di Sekolah Dasar
}

\author{
Mustika Firdausi ${ }^{1}$,Taufina ${ }^{2}$ \\ Universitas Negeri Padang, Sumatera Barat, Indonesia ${ }^{1,2}$ \\ E-mail: mustikafirdausi026@gmail.com¹ ${ }^{1}$ taufina_taufik@yahoo.co.id ${ }^{2}$
}

\begin{abstract}
Abstrak
Penelitian ini bertujuan untuk meneliti cara meningkatkan kualitas keterampilan sosial dengan model Kooperatif Teams Game Turnament pelajaran Ilmu Pengetahuan Sosial peserta didik kelas IV SDN 21 Jalan Kereta Api Kota Pariaman. Subjeknya yaitu peserta didik kelas IV SDN 21 Jalan Kereta Api. 19 peserta didik yaitu delapan pria dan sebelas wanita. Hasil penelitian menunjukkan dengan menggunakan model Kooperatif Teams Game Turnament dapat meningkatkan keterampilan sosial siswa di kelas IV SD Negeri 21 Jalan Kereta Api Kota Pariaman. Hasil observasi keterampilan sosial pada siklus I dan meningkat pada siklus II yaitu $36,84 \%$ meningkat menjadi $89,47 \%$. Kemudian rata-rata siklus I yaitu 65,79 meningkat pada siklus II dengan rata-rata $85,16$.
\end{abstract}

Kata kunci : kooperatif teams game turnament, keterampilan sosial, IPS

\begin{abstract}
This article aims to examine how to improve the quality of social skills with the Cooperative Teams Game Tournament model of social science lessons for students in grade IV SDN 21 Jalan Kereta Pariaman. The subjects were grade IV students of SDN 21 Jalan Kereta 19, namely eight male students and eleven women. The results showed that using the Cooperative Teams Game Tournament model could improve students' social skills in class IV SD Negeri 21 Jalan Kereta Pariaman. The results of observation of social skills in the first cycle and increased in the second cycle is $36.84 \%$ increased to $89.47 \%$. Then the cycle I average of 65.79 increased in the second cycle with an average of 85.16.
\end{abstract}

Keywords: cooperative teams game tournament, social skills, social sciences

Copyright (c) 2020 Mustika Firdausi,Taufina

$\square$ Corresponding author :

Address : Air Tawar Padang

Email : mustikafirdausi026@gmail.com

ISSN 2580-3735 (Media Cetak)

Phone : 082382761577

ISSN 2580-1147 (Media Online)

DOI: $10.31004 /$ basicedu.v4i4.455 


\section{PENDAHULUAN}

Ada banyak keterampilan sosial yang penting bagi anak-anak untuk dipahami. Karena keterampilan sosial diperoleh dari waktu ke waktu sesuai pertumbuhan anak, jadi orang tua dan guru harus bisa memahami tahap-tahap perkembangan anak tersebut. Anak-anak yang berkembang akan kesulitan untuk menyesuaikan diri sendiri kepada temannya. Dengan begitu guru perlu memastikan siswa memperoleh keterampilan yang diperlukan untuk interaksi sosial yang sukses (Omer, 1979). Terkadang dengan tidak berjalannya interaksi sosial dengan baik akan mengakibatkan beberapa perkembangan yang buruk dan anak menjadi kesulitan belajar karena hal itu.

$$
\text { Anak-anak selalu menghadapi }
$$
perkembangan yang berbeda. Kunci dari anak yang sosial yaitu memiliki keterampilan seperti mendengarkan dengan hati-hati, merespons dengan penuh pertimbangan kepada orang lain, mengenali perilaku non-verbal dan verbal secara berbagi dan bekerja sama, sesuai ketegasan, dan secara efektif mengatur sendiri emosi dan perilaku, mereka cenderung memiliki perkembangan, cara dia berteman, membentuk kelompok dan atau grup. Hubungan dengan teman dapat terjalin dengan baik karena beberapa hal yaitu kesamaan usia anak, situasi, keakraban, ukuran, dan kelompok tertentu. Hal ini saling mendukung, jika tidak adanya keakraban, anak akan cenderung membuat hubungan pertemanan dengan baik, biasanya akan menghasut teman lainnya untuk membuat kelompok, hubungan anak-anak dengan teman sebayanya menuju kearah yang positif dan terarah dengan baik (Hygen et al., 2019).
Dengan adanya keterlibatan orang tua akan membuat anak-anak berhasil dalam berpotensi, karena sifat orang tua sangat berpengaruh terhadap anak. Anak itu dikatakan unik karena efek sifat orang tua menjadi lebih positif dalam persepsi kompetensi mereka dan fungsi emosional. Tanggung jawab keluarga dalam kehidupan anakanak yaitu membuat kepribadian anak yang positif serta berkarakter, ada kala orang tua harus nasehati anaknya dan memperbaiki hal yang salah dilakukan anak-anak dilakukannya (Cheung \& Pomerantz, 2011). Anak harus memiliki tingkat bersosialisasi yang sedang saja, jika tingkat sosial anak tinggi, maka mental anak akan cepat lelah dan jika sosial anak terlalu rendah maka akan membuat anak jadi tidak berguna dan penakut. Anak juga akan cenderung mencari panutan di sekitaran lingkungannya, untuk belajar bersosialisasi, membuat keputusan, dan berperilaku.

Karena hubungan dan emosional sangat mempengaruhi perkembangan anak, sekolah dan keluarga harus secara efektif menangani aspekaspek ini dari proses pendidikan. Karena emosi dapat memfasilitasi atau menghambat akademik anak-anak, keterlibatan, etos kerja, komitmen, dan keberhasilan sekolah. Ini merupakan tantangan untuk guru dan orang tua untuk menangani keterampilan anak tersebut. Karena banyak anak yang berbeda dari beraneka ragam budaya dengan kemampuan yang beragam dan motivasi untuk belajar sehingga banyak siswa kurang kompetensi sosial-emosional saat mereka di sekolah dasar sehingga berdampak negatif terhadap kinerja akademik mereka,perilaku, dan kesehatan (Durlak 
et al., 2011). Interaksi dengan teman sebaya terjadi dengan beberapa ekspresi emosional. Dengan demikian, cara orang tua mengajarkan anaknya dapat mempengaruhi anaknya bersikap terhadap teman sebaya, karena anak cenderung mencontoh bagaimana lingkungannya di rumah. Orang tua tidak dapat membantu ketika anaknya belajar mangatur emosi mereka karena anak cenderung sudah memiliki sikap yang susah buat diubah karena semua tergantung bagaimana orang tua mempengaruhinya juga dari tahap pertumbuhannya sehingga membangun siklus tanggapan sebagai anak, mereka mungkin diperlakukan dengan cara yang sama bagaimana mereka sekarang merespons anak-anak mereka sendiri. Tentu saja, tidak mungkin untuk mengetahui apakah anak-anak yang ditampilkan proporsi negatif rendah (Fabes et al., 2001).

Kurangnya perhatian pada faktor-faktor hubungan sosial dan emosi dapat mempengaruhi pemikiran anak. Emosi ini dihasilkan oleh makhluk melalui penilaian peristiwa sehubungan dengan tujuan spesifik. Ketika anak-anak berkembang, interaksi yang konstan ini antara fungsi kognitif dan emosional mereka memunculkan peningkatan kemampuan mereka untuk merenungkan dan memahami emosi mereka, pertimbangkan kinerja orang lain melihat, dan menghambat atau merencanakan tindakan mereka(Suizzo, 2000). Dalam pembelajaran IPS, guru bisa mengembangkan aspek keterampilan sosial siswa, agar proses pembelajarannya dapat meningkatkan perkembangan sosial, emosi yang positif, yang dimiliki anak. Dalam meningkatkan keterampilan sosial, guru perlu memilih dan menggunakan strategi dengan model sangat optimal serta lebih menarik.

Dalam pembelajaran IPS saat pembelajaran ada beberapa permasalahan yang ditemukan yaitu : interaksi antara guru dan orang tua siswa yang jarang, perbedaan gender yang menonjol dalam kehidupan sehari-hari, bagi negara yang masih dalam peperangan, masih belum berpikiran membuat kurikulum, kerangka kerja yang belum tepat, kurang kompetensi sosial-emosional saat mereka di sekolah dasar sehingga berdampak negatif terhadap kinerja akademik mereka, perilaku, dan kesehatan, rendahnya hasil belajar siswa, pencapaian indikator yang belum sesuai dengan intake siswa, guru masih menggunakan metode konvensional, kurang menggunakan media pembelajaran bervariasi, motivasi, minat belajar kreativitas dan berpikir kritis siswa yang kurang. Kerja sama antara sekolah dan orang tua masih kurang dan pelatihan tentang pelajaran IPS masih kurang.

Maka dari itu, maka dibutuhkan model dalam mencapai keterampilan sosial dengan perkembangan emosi dan sosial. Model yang sangat menarik dalam proses pembelajaran (Afita, 2015). Untuk meningkatkan keterampilan sosial yaitu modelCooperatif Teams Game Turnament. Model/metode ini hal yang sangat gampang untuk sebuah pembelajaran dari semua akademik (Fitriyah, 2019).

Berdasarkan permasalahan, peneliti terminat untuk meneliti dengan judul Penggunaan Model Kooperatif Teams Game Turnament Untuk Meningkatkan Keterampilan Sosial Anak Pada Pembelajaran IPS Di SDN 21 Jalan Kereta Api. 


\section{METODE}

Penelitian ini yaitu penelitian Action Research yang menggunakan penggunaan Model Kooperatif Teams Game Turnament untuk meningkatkan keterampilan sosial anak pada pembelajaran IPS di SDN 21 Jalan Kereta Api. Subjeknya yaitu peserta didik kelas IV SDN 21 Jalan Kereta Api. 19 peserta didik yaitu delapan pria dan sebelas wanita. Objeknya yaitu penggunaan model kooperatif teams game turnament. Penelitian ini menggunakan instrumen yaitu observasi dan dokumentasi.

Analisis data dalam penelitian deskriptif yaitu dikerjakan berdasarkan data yang dikumpulkan. Adapun bagian analisis data yaitu :

1. Gambaran data yang didapat dari catt.lapangan dengan dokumentasi/foto. Hasil observasi peneliti mulai dari kegiatan awal, kegiatan inti dan kegiatan penutup, hasil observasi.

2. Keaadaan yang sebenarnya pada satuan sekolah.

\section{HASIL DAN PEMBAHASAN}

Ilmu Pengetahuan Sosial (IPS) yaitu yang terdapat didalamnya beberpa muatan pembelajaran yang berhubungan dengan geografi, sejarah, sosiologi, ekonomi dengan mempelajari ini peserta didik menjadi orang yang memiliki jiwa sosial terhadap negaranya (Desnarita, 2019). Pembelajaran IPS merupakan pembelajaran yang harus di laksanakan dengan model yang dapat meningkatkan pembelajarannya agar peserta didik menjadi yang berkarakter dan menjadi orang yang bersosial.
Tujuan dari sebuah pembelajaran ilmu pengetahuan sosial adalah mencerna dan meluaskan ilmu, hasil, kelakuan, keterampilan sosial, fakta, konsep, serta generalisasi pada bermasyarakat (Susanto, 2014).

Keterampilan sosial (social skills) yaitu keahlian perorangan untuk mengadakan interaksi kepada orang dan keahlian menyudahi suatu masalah , supaya semua warga menjadi akrab. Ciri-ciri keterampilan sosial, yaitu: 1) sikap dalam seorang, yaitu sikap interaktif menjadi saling membantu, 2) sikap luar seseorang, keahlian membuat diri dalam keadaan bermasyarakat, 3) sikap akademis, sikap dalam keberhasilan pendidikan, 4) perilaku menerima dalam jenis dan usia untuk berinteraksi. Cakupan pada diri peserta didik yaitu: (a) kemampuan berbicara, (b) kemampuan menulis, dan (b) Kekompakkan (J.P. Chaplin, 1981).

Keterampilan sosial berasal dari dua kata yaitu keterampilan (skill) dan sosial. Keterampilan (skill) yaitu keahlian yang dilakukan orang dalam bergerak dengan benar (J.P. Chaplin, 1981). Sedangkan sosial berasal dari societas yang artinya masyarakat dan bahasa latin socius artinya kawan. Dengan kawan lainnya kekeluargaan, satuan pendidik, dan lain (Ahmadi, 2009).

Ada banyak keterampilan sosial yang penting bagi anak-anak untuk dipahami. Karena keterampilan sosial diperoleh dari waktu ke waktu sesuai pertumbuhan anak, jadi orang tua dan guru harus bisa memahami tahap-tahap perkembangan anak tersebut. Anak-anak yang berkembang akan kesulitan untuk menyesuaikan diri sendiri kepada temannya. Dengan begitu guru perlu memastikan 
siswa memperoleh keterampilan yang diperlukan untuk interaksi sosial yang sukses (Omer, 1979).

Selain itu keterampilan social yaitu bagaimana cara kita berbicara dan bergotong royong dan saling memberi dan berinteraksi dengan sikap yang baik (Rahayu, 2014).

Team Games Tournament yaitu yang mampu membuat peserta didik beraktivitas tanpa perbedaan usia jenis dan kelamin. Dan adanya game serta penguatan. Pembelajaran TGT ini membuat peserta didik menjadi sangat bersemangat karena adanya permainan dan penghargaan, pesrta didik juga dapat menjadi sangat lebih baik (Chotimah, 2009). Maka dari itu pembelajaran harus didukung oleh model yang sangat menarik dan menyenangkan yaitu model TGT. Permainan dalam bentuk kuis dengan menjawab pertanyaan sesuai pembelajaran sesame kelompok (Trianto-M.Pd_.-Mendesain-ModelPembelajaran-Inovatif-Progresif.-Intro.Pdf, n.d.)

Langkah-langkah model TGT (Solihah, 2016):

1) Memaparkan pokok pembahasan

2) Membentuk grop

3) Games turnaments

4) Reward kepada grop

Ada lima(5) langkah (TGT), yaitu: (1) persiapan ruang , (2) grup, (3) game, (4) persaingan (5) hadiah grup (Taniredja, 2013).

Keunggulan TGT, sebagai berikut.

1) Peserta didik lebih signifikan lebih banyak dari peserta didik model lama

2) Meningginya persiapan peserta didik tergantung keefektifan di dalam kelas
3) Meningginya kepercayaan diri peserta didik

4) Meningginya kerja sama peserta didik

5) Kekompakkan peserta didik sangat tinggi dengan Timer yang diperlukan panjang

6) Meningginya kerajinan peserta didik ke sekolah

Menurut Sudjana keunggulan dari model yaitu :

1) Durasi yang banyak

2) Mengemukakan penerimaan kepada perbedaan pe orangan;

3) Waktu yang pendek dapat memperdalam materi-materi yang ada

4) Aktifnya di kelas

5) Mengajarkan dikelas dalam berinteraksi kepada orang orang

6) Proses dan hasil belajar akan bagus

Menurut Chotimah, (2009) Kelebihan pembelajaran kooperatif tipe TGT yaitu pembelajaran langsung ke peserta didik dan menyenangkan dalam prosesnya.

Kekurangan model pembelajaran TGT, yaitu

1) Pembelejaran yang terlalu lama

2) Pembelajaran harus berlanjut

3) Peserta didik susah mengingat kembali

Hasil observasi pada keterampilan sosial pada siklus I yaitu kemampuan interaksi yang tidak bagus pada kelas IV SD Negeri 21 Jalan Kereta Api pada pelajaran ilmu pengetahuan sosial. Terlihat dari interaki mereka bersama temannya, cara mereka berbicara sesama temannya masih kurang sopan dan dengan cara emosi yang 
tidak terkontrol dalam bermain. Hal tersebut terlihat dari hampir semua siswa di dalam kelas selalu bersorak kurang sopan di kelas pada hari itu. Pada siklus II keterampilan sosialnya semakin baik dan meningkat. Proses belajar mengajar pada siklus I dengan teman sebayanya sudah mulai membaik tetapi belum paham dengan interaksi dengan gurunya.

Pada pelajaran IPS interaksi antara guru dan orang tua siswa yang jarang, perbedaan gender yang menonjol dalam kehidupan sehari-hari. Bagi negara yang masih dalam peperangan, masih belum berpikiran membuat kurikulum, kerangka kerja yang belum tepat, kurang kompetensi sosialemosional saat mereka di sekolah dasar sehingga berdampak negatif terhadap kinerja akademik mereka,perilaku, dan kesehatan rendahnya hasil belajar siswa, pencapaian indikator yang belum sesuai dengan intake siswa, guru belum maksimal menguasai materi pembelajaran ips, gurumasih menggunakan metode konvensional, kurang menggunakan media pembelajaran bervariasi, motivasi, minat belajar kreativitas dan berpikir kritis siswa yang kurang, kerja sama antara sekolah dan orang tua masih kurang dan pelatihan tentangpelajaran IPS masih kurang. Sedangkan pada siklus II proses belajar mengajarnya sudah meningkat menjadi lebih menarik dan siswa paham dengan model TGT tersebut, mereka menjadi fokus dan serius di kelas.

Hasil observasi keterampilan sosial pada siklus I meningkat pada siklus II yaitu $36,84 \%$ meningkat menjadi $89,47 \%$. Dengan KKM $75 \%$. Kemudian rata-rata siklus I yaitu 65,79 meningkat pada siklus II dengan rata-rata 85,16. Maka dari siklus II sudah meningkat, maka peneliti meneliti hanya sampai siklus II.

Maka hasil observasi keterampilan sosial di kelas IV SDN 21 Jalan Kereta Api Kota Pariaman diperoleh hasil seperti dibawah ini.

Tabel 1. Hasil Observasi Keterampilan Sosial Kelas IV SDN 21 Jalan Kerata Api Kota Pariaman

\begin{tabular}{|c|c|c|c|}
\hline Siklus & $\begin{array}{c}\text { Persentase dan } \\
\text { Jumlah Siswa } \\
\text { yang Telah } \\
\text { Mencapai Nilai } \\
>75\end{array}$ & $\begin{array}{c}\text { Nilai } \\
\text { Rata-rata } \\
\text { secara } \\
\text { Klasikal }\end{array}$ & Ket \\
\hline 1 & 2 & 3 & 4 \\
\hline $\begin{array}{c}\text { Siklus } \\
\text { I }\end{array}$ & $36,84 \%$ (7 orang) & 65,79 & $\begin{array}{l}\text { Belum } \\
\text { tuntas }\end{array}$ \\
\hline $\begin{array}{l}\text { Siklus } \\
\text { II }\end{array}$ & $\begin{array}{c}89,47 \%(17 \\
\text { orang) }\end{array}$ & 85,16 & Tuntas \\
\hline
\end{tabular}

\section{KESIMPULAN}

Berdasarkan hasil penelitian dan pembahasan maka dapat disimpulkan yaitu hasil observasi keterampilan sosial dari siklus I meningkat pada siklus II yaitu $36,84 \%$ meningkat menjadi 89,47\%. Dengan KKM $75 \%$. Kemudian rata-rata siklus I yaitu 65,79 dapat meningkat pada siklus II dengan rata-rata 85,16.

\section{DAFTAR PUSTAKA}

Afita, M. (2015). Penerapan Model Pembelajaran Kooperatif Tipe Teams Game Tournament (TGT) Untuk Meningkatkan Hasil Belajar IPS Materi Peristiwa Sekitar Proklamasi Siswa Kelas VB MI Muhammadiyah Pengadegan Knecamata Pengadegan Kabupaten Purbalingga Tahun Pelajaran 2014/201. Journal of Chemical Information and Modeling, 53(9), 1689-1699. https://doi.org/10.1017/CBO9781107415324. 004 
Ahmadi, H. A. (2009). Psikologi Sosial. Rineka Cipta.

Cheung, C. S. S., \& Pomerantz, E. M. (2011). Parents' Involvement in Children's Learning in the United States and China: Implications for Children's Academic and Emotional Adjustment. Child Development, 82(3), 932$950 . \quad$ https://doi.org/10.1111/j.14678624.2011.01582.x

Desnarita. (2019). Jurnal basicedu. Jurnal Basicedu, 3(2), 524-532.

Durlak, J. A., Weissberg, R. P., Dymnicki, A. B., Taylor, R. D., \& Schellinger, K. B. (2011). The Impact of Enhancing Students' Social and Emotional Learning: A Meta-Analysis of School-Based Universal Interventions. Child Development, 82(1), 405-432. https://doi.org/10.1111/j.1467-

8624.2010.01564.x

Fabes, R. A., Leonard, S. A., Kupanoff, K., \& Martin, C. L. (2001). Parental coping with children's negative emotions: Relations with children'... Child Development, 72(3), 907$920 . \quad$ https://doi.org/10.1111/14678624.00323

Fitriyah, D. (2019). Pengaruh Metode Teams Games Tournament (TGT) Terhadap Hasil Belajar Subtema Perubahan Lingkungan Siswa Kelas 5 MI Yaspuri Malang. Journal of Chemical Information and Modeling, 53(9), 1689-1699. https://doi.org/10.1017/CBO9781107415324. 004

Hygen, B. W., Zahl-Thanem, T., Wichstrøm, L., Belsky, J., Stenseng, F., Kvande, M. N., \& Skalicka, V. (2019). Time Spent Gaming and Social Competence in Children: Reciprocal Effects Across Childhood. Child Development, $\quad 00(0), \quad 1-15$. https://doi.org/10.1111/cdev.13243

J.P. Chaplin. (1981). Kamus Lengkap Psikologi. PT. Raja Grafindo Persada.

Omer, S. (1979). Social Development. International Social Work, 22(3), 11-26. https://doi.org/10.1177/00208728790220030 3

Rahayu, D. \& S. I. S. \& A. (2014). Peningkatan Keterampilan Sosial Anak Usia Dini Melalui Tradisional, Permainan. Journal of Chemical Information and Modeling, Antologi UPI, 8, $1-9$.

https://doi.org/10.1017/CBO9781107415324. 004

Solihah, A. (2016). Pengaruh Model Pembelajaran Teams Games Tournament (TGT) Terhadap Hasil Belajar Mateamatika. 1(1), 45-53. Jurnal SAP Vol. 1 No. 1 Agustus 2016

Suizzo, M. A. (2000). The social-emotional and cultural contexts of cognitive development: Neo-Piagetian perspectives. Child Development, $\quad$ 71(4), 846-849. https://doi.org/10.1111/1467-8624.00191

Susanto, A. (2014). Pengembangan Pembelajaran IPS di Sekolah Dasar. Kencana. http://lib.faiumj.ac.id//index.php?p=show_detail\&id=238 74

Taniredja, T. (2013). Model-model pembelajaran Inovatif dan Efektif. Alfabeta.

Trianto-M.Pd_.-Mendesain-Model-PembelajaranInovatif-Progresif.-Intro.Pdf. (n.d.). 